\title{
Theophylline Effects on Cellular Response in Protein-Energy Malnourished Neonatal Rat Brain
}

\author{
GRIFFITH E. QUINBY JR. ${ }^{(18)}$ AND TETSUO NAKAMOTO \\ Departments of Pediatrics and Physiology, Louisiana State University Medical Center, \\ New Orleans, Louisiana, USA
}

\begin{abstract}
Summary
The present study employed an animal model in an attempt to document effects on brain growth of long-term exposure to theophylline in the presence or absence of malnutrition.

One group of dams was randomly divided into half. One-half was fed a $20 \%$ protein diet and the other half a $6 \%$ protein diet. Similarly, a second group of dams was also randomly divided into two groups. These were pair-fed with rats of the first group, receiving diets comparable to those in group one but to which theophylline was added in amounts calculated to provide daily doses of $2 \mathrm{mg} / 100 \mathrm{~g}$ of body weight. Theophylline supplementation in the dams' $6 \%$ protein diet decreased the body weight of the pups consistently from d 3 to the end of the study at $d 15$ in comparison to the non-theophylline group. In contrast, the presence of theophylline in the control diet increased the body weight of the pups at $d \mathbf{1 5}$ compared with that of the non-theophylline group. Brain weight was essentially identical in the normal controls and the normally nourished group given theophylline. No difference in brain weight was noted between the malnourished group and the malnourished group given theophylline.

We found a significant reduction in DNA content per brain or per $\mathrm{mg}$ of brain weight in the normally nourished group given theophylline compared with non-theophylline group. DNA values per mg of brain weight from the controls that received theophylline were not different from either malnourished group. RNA, expressed as $\mu \mathrm{g}$ RNA per mg brain weight, was significantly reduced in the normally nourished group that received theophylline when compared with the normally nourished controls and the malnourished group that received theophylline.
\end{abstract}

Total protein content per brain was significantly reduced in the malnourished group that received theophylline compared with non-theophylline group. A significant increase in the amount of protein in the malnourished groups as opposed to the normally nourished groups was measured ( $\mu$ g protein per mg brain).

The brain cell size (protein:DNA) calculated by the standard method in the malnourished group supplemented with theophylline was smaller compared with that of the non-theophylline group, but cell size in the control group given theophylline was greater. It appears that theophylline supplementation in the maternal diet affects the cell size differently according to the nutritonal state of the offspring.

Our data suggest that, in the animal model, the administration of theophylline in the presence of a compromised nutritional status may have effects not now apparent. We add our concern to that expressed by others that methylxanthine administration may have previously unsuspected effects on the developing brain.

In 1973, theophylline (1,3-dimethylxanthine) was shown to be an effective therapeutic agent for the treatment of apnea in neonates (5). Since this original report, theophylline and, to a lesser extent caffeine, have become widely used in the management of apnea in the newborn, especially the premature. As with many recently discovered techniques that are used widely, little is known about long-term effects on growth and development. Clinical studies to date have not demonstrated ill effects directly attributable to theophylline (9).

Current clinical practice does not take the nutritional status of the infant into account when theophylline is administered for apnea. Many of the disease states and/or anomalies common in neonatal units are associated with significant malnutrition. When apneic episodes occur in such infants, intravenously administered theophylline is frequently added to the therapeutic regimen. Using an animal model, the present study attempts to document effects on brain growth of long-term exposure to theophylline in the presence or absence of malnutrition.

\section{MATERIALS AND METHODS}

Sixteen timed-pregnant Sprague-Dawley rats (Holtzman strain) were purchased from the breeder. Dams were fed standard laboratory chow until pups were delivered. Several litters were combined if the time of delivery was within a range of $8 \mathrm{~h}$. As there is no nutritional difference attributable to sex in early ages (8), eight randomly selected pups were assigned to each dam and their ages designated as $d 1$. The first group of dams was randomly divided into half. One-half was fed a $20 \%$ protein diet and the other half a $6 \%$ protein diet. Similarly, the second group of dams was also randomly divided into two groups. These were pair-fed with rats of the first group, receiving diets comparable to those in group one, but to which theophylline was added in amounts calculated to provide daily doses of $2 \mathrm{mg} / 100 \mathrm{~g}$ of body weight (17). The source of the protein was casein. Diets of malnourished rats, in comparison, were isoenergetic but provided only $6 \%$ protein. The difference in energy was made up by addition of dextrose and dextrin, as modified from previously described dietary composition (8) (Table 1).

The dams and pups were weighed every other day. On d 15 , groups of pups were sacrificed and the brain was removed and weighed. The brain was homogenized with a Teflon homogenizing apparatus to determine DNA, RNA, and protein content. DNA and RNA content were meaured by the method of Prasad et al. (12), and protein content was measured by the method of Lowry et al. (6). Another group of randomly selected pups from each dam was injected with methyl $\left[{ }^{3} \mathrm{H}\right]$ thymidine $(74.9 \mathrm{Ci} /$ mmol, New England Nuclear, Boston, MA) at a dose of $25 \mu \mathrm{Ci}$ / $100 \mathrm{~g}$ of body weight and returned to their dam for $1 \mathrm{~h}$ after which they were sacrificed by decapitation. The brain was rapidly removed, weighed, and then homogenized. An aliquot was used to determine total DNA. In another aliquot (2 ml), DNA was extracted according to the method of Keenan et al. (4). A 0.5 $\mathrm{ml}$ aliquot of this extract was counted using a toluene-PPO scintillation fluid containing $33 \%$ Triton X-100, in a Beckman 
L3145T scintillation counter (Beckman Instruments, Irvine, CA). Correction for quench was by external standard.

Data were analyzed using multiple comparison analysis of variance (Student-Newman-Keuls) with 5\% considered significant. Analyses were performed on an Apple II microcomputer (Apple Corp., Cupertino, CA).

\section{RESULTS}

As expected, pups of dams fed the $6 \%$ protein diet were much smaller than the pups of normally nourished controls. The body weight of the malnourished group given theophylline was smaller than the group subjected to malnutrition alone from $\mathrm{d} 3$ onward. In the normally nourished groups, no difference in body weight was noted in the theophylline-treated group as compared with its control until d 15 when the theophylline group became larger (Table 2).

The control dams consumed $33.92 \pm 6.31 \mathrm{~g}$ (mean $\pm \mathrm{SD}$ ) of diet daily whereas their pair-fed counterparts consumed $32.33 \pm$ $6.64 \mathrm{~g}$ daily of the theophylline-supplemented diet. Malnourished dams consumed $16.36 \pm 1.78 \mathrm{~g}$ of diet daily, and malnourished dams fed theophylline with the $6 \%$ protein diet consumed 14.66 $\pm 2.7 \mathrm{~g}$ daily. There are no statistically significant differences within these groups.

Brain weight was essentially identical in the normal controls and the normally nourished group given theophylline. No difference in brain weight was noted between the malnourished group and the malnourished group given theophylline (Table 3). The brains of the normally nourished groups were larger than those of the malnourished groups.

We found a significant reduction in DNA content per brain or per mg of brain weight in the normally nourished group given theophylline compared with the non-theophylline group. The normally nourished control group had significantly more DNA than the malnourished group. No difference was noted in DNA content per brain or per mg of brain tissue between the mal-

Table 1. Diet composition ( $g$ )

\begin{tabular}{lcccc}
\hline & $\begin{array}{c}20 \% \\
\text { Protein }\end{array}$ & $\begin{array}{c}\text { 20\% Protein } \\
+ \text { theophylline }\end{array}$ & $\begin{array}{c}6 \% \\
\text { Protein }\end{array}$ & $\begin{array}{c}6 \% \text { Protein } \\
+ \text { theophylline }\end{array}$ \\
\hline Casein & 200 & 200 & 60 & 60 \\
Dextrose & 192 & 192 & 267 & 267 \\
Sucrose & 178 & 178 & 172 & 172 \\
Dextrin & 192 & 192 & 262 & 262 \\
Corn oil & $150 \mathrm{ml}$ & $150 \mathrm{ml}$ & $150 \mathrm{ml}$ & $150 \mathrm{ml}$ \\
Mineral mix* & 40 & 40 & 40 & 40 \\
Choline chloride & $4 \mathrm{ml}$ & $4 \mathrm{ml}$ & $4 \mathrm{ml}$ & $4 \mathrm{ml}$ \\
$\quad(50 \%$ w/v) & & & & \\
Cellulose & 35 & 35 & 35 & 35 \\
Vitamin mix $\dagger$ & 10 & 10 & 10 & 10 \\
Methionine & & & 1.0 & 1.0 \\
Theophylline & & 0.185 & & 0.290 \\
\hline
\end{tabular}

* Rogers-Harper mineral mix (Teklad Test Diets, Madison, WI).

† AIN vitamin mixture 76 (ICN Pharmaceuticals, Inc., Cleveland, $\mathrm{OH})$ nourished group and the malnourished group that received theophylline. DNA values per mg of brain weight from the controls that received theophylline were not different from either malnourished group (Table 4).

Total RNA content per brain did not significantly differ between any groups, although it was slightly lower in the normally nourished group who received theophylline. RNA, expressed as $\mu \mathrm{g}$ RNA per mg brain weight, was significantly reduced in the normally nourished group that received theophylline when compared with the normally nourished controls and the malnourished group that received theophylline (Table 4).

Total protein content per brain was significantly reduced in the malnourished group that received theophylline compared with the non-theophylline group. No statistically significant differences were noted between the normally nourished controls and the normally nourished group that received theophylline (Table 4). The malnourished theophylline group had a significantly lower protein content than the normally nourished theophylline group. Expressed as $\mu \mathrm{g}$ protein per mg brain weight, neither the administration of theophylline nor its lack resulted in differences within groups for the control or malnourished animals. A significant increase was measured in the amount of protein in the malnourished groups as opposed to the normally nourished groups (Table 4). No differences were noted in the rate of $\left[{ }^{3} \mathrm{H}\right]$ thymidine incorporation into DNA in any group (Table 4).

\section{DISCUSSION}

Theophylline consumed by dams is known to pass through their milk to their offspring (1). Although some pups may begin attempts to eat the dam's food around d 15, most of the offsprings' nutritional intake comes from the dam's milk. The theophylline effects observed in the pups in the present study occurred as a result of theophylline passage through the dams' milk.

Theophylline supplementation in the dams' $6 \%$ protein diet decreased the body weight of the pups consistently from $\mathrm{d} 3$ to the end of the study at $d 15$ compared with the non-theophylline group (Table 2). In contrast, the presence of theophylline in the control diet increased the body weight of the pups at $d 15$ compared with that of the non-theophylline group. These observations suggest that the effects of theophylline on the body growth of the pups may be related to the maternal dietary protein content. Theophylline added to the maternal diet seems to exert some adverse effects in a short time on the protein-energy malnourished pups compared with the non-theophylline group.

Although the mechanism of these findings is still unexplained, it has been reported that some nutritional conditions may not only modify the toxicity of chemical products and the therapeutic efficacy of some drugs (7), but also modulate the tissue's sensitivity to drugs (13). Perhaps the rat pups' response to theophylline depends upon their nutritional state.

It should be noted that, although the body weight of the pups in both malnourished and control groups was affected in the theophylline groups, the brain weight of the pups showed no

Table 2. Weight of pups $(g)^{*}$

\begin{tabular}{|c|c|c|c|c|c|}
\hline \multirow[b]{2}{*}{ Maternal diet } & \multicolumn{5}{|c|}{ Age of pups (d) } \\
\hline & 3 & 6 & 9 & 12 & 15 \\
\hline $20 \%$ Protein & $9.27 \pm 0.83$ & $14.98 \pm 1.74$ & $20.69 \pm 2.55$ & $27.11 \pm 3.96$ & $33.09 \pm 5.16$ \\
\hline $20 \%$ Protein + theophylline & $9.23 \pm 0.74$ & $14.64 \pm 1.62$ & $21.25 \pm 2.85$ & $28.48 \pm 3.56$ & $35.86 \pm 4.54 \ddagger t$ \\
\hline $6 \%$ Protein & $8.70 \pm 0.93$ & $11.57 \pm 1.12$ & $13.59 \pm 1.82$ & $15.62 \pm 2.02$ & $17.25 \pm 2.39$ \\
\hline $6 \%$ Protein + theophylline & $8.04 \pm 0.77$ & $9.84 \pm 1.14 \$ t$ & $11.49 \pm 0.99 \ddagger t$ & $13.42 \pm 1.19 \ddagger t$ & $14.54 \pm 1.42 \S t$ \\
\hline
\end{tabular}

* Each value represents mean \pm SD of 32 pups.

$t$, significant difference due to theophylline effect alone (i.e., $20 \%$ vs $20 \%+$ theophylline; $6 \%$ vs $6 \%+$ theophylline).

$\$ P<0.05$.

$\S P<0.01$. 
statistically significant difference within groups at the time of sacrifice. If the data are expressed as a ratio of brain weight to the body weight on d 15, one finds that the brains of the malnourished pups given theophylline are larger relative to body weight whereas the brains of the control pups given theophylline are slightly smaller relative to body weight compared with those of the non-theophylline group. These observations imply that theophylline may have differing effects on brain growth and may resist the effects of malnutrition on brain growth relative to the somatic growth.

If the amounts of DNA (cell number) are expressed as DNA per unit weight of brain or as DNA per brain, the malnourished pups showed no effect on brain cell number attributable to theophylline. In contrast, the normally nourished pups, regardless of how the data are expressed, showed a substantial decrement in brain cell number in the group given theophylline compared with the non-theophylline group. We conclude that theophylline does not affect brain cell number in malnourished animals any more than malnutrition alone. On the other hand, the normally nourished animal seems more vulnerable to theophylline's effects on brain cell number. Malnutrition may render the animal incapable of responding to theophylline as does the normally nourished control. This may be an unusual example of a complex drug-nutrition interaction, in that malnutrition usually increases sensitivity to toxic effects of drugs or chemicals (10). In this system, the effect of theophylline on cell number is apparently blunted by malnutrition.

Theophylline has been reported to suppress cholesterol synthesis, but not DNA synthesis, in rat glial cells in vitro (16). In the present in vivo study, there was no difference seen in DNA

Table 3. Brain weights $(m g)^{*}$

\begin{tabular}{lc}
\multicolumn{1}{c}{ Maternal diet } & Brain wt \\
\hline $\begin{array}{l}20 \% \text { Protein } \\
(n=18)\end{array}$ & $1340 \pm 33$ \\
$20 \%$ Protein + theophylline & $1339 \pm 89$ \\
$\quad(n=16)$ & $1066 \pm 78 \mp \mathrm{d}$ \\
$6 \%$ Protein & $(n=10)$ \\
$6 \%$ Protein + theophylline & $1024 \pm 49 \ddagger \mathrm{d}$ \\
$(n=13)$ & \\
\hline
\end{tabular}

* Each value represents mean $\pm \mathrm{SD}$.

$\mathrm{d}$, significant difference due to dietary effect alone (i.e., $20 \%$ vs $6 \%$; $20 \%+$ theophylline vs $6 \%+$ theophylline). $\ddagger P<0.01$. synthesis measured by $\left[{ }^{3} \mathrm{H}\right]$ thymidine uptake regardless of theophylline supplementation in both malnourished and control brains. In adult rats, using a protein-free diet, Pastorova et al. (11) found that $\left[{ }^{14} \mathrm{C}\right]$ thymidine uptake into brain DNA in animals fed the protein-deficient diet did not show a significant difference compared with the uptake of the controls. Similar rates of $\left[{ }^{3} \mathrm{H}\right]$ thymidine incorporation into DNA despite the different amount of total DNA content in each group, although surprising, might be explained on the basis that the $\left[{ }^{3} \mathrm{H}\right]$ thymidine uptake peak might have been shifted by the nutritional as well as theophylline effects. We could have observed an apparently similar rate of DNA synthesis between the groups.

Although the total protein content in the malnourished group per mg of brain weight showed no difference between the theophylline and the non-theophylline group, when the data are expressed as protein content per brain, total protein content was smaller in the theophylline-supplemented group. This discrepancy may be due to slightly smaller brain weight (approximately $4 \%$ ) on the average in the malnourished group with theophylline than that of the non-theophylline group. Because theophylline is known to inhibit cholesterol synthesis (16), the diminished protein content of the theophylline-supplemented malnourished group might be due to a resultant reduction of total myelin synthesis.

The brain cell size (protein:DNA) calculated by the standard method $(3,15)$ in the malnourished group supplemented with theophylline was smaller compared with that of the non-theophylline group, but cell size in the control group given theophylline was greater. Apparently, theophylline supplementation in the maternal diet affects the cell size according to the nutritional state of the offspring. Winick and Noble (15) induced proteinenergy malnutrition in rat pups for the first $21 \mathrm{~d}$ of life. In animals they sacrificed immediately after the period of malnutrition, the cell size, as estimated by the protein/DNA ratio, had increased from 44.1 in controls to 56.9 in the malnourished group. Although statistical analyses were not available in their study, it appears that average brain cell size was increased in the malnourished group. In the present study, brain cell size in the malnourished group without theophylline was greater than that of the normally nourished controls without theophylline.

RNA/DNA, an index of cellular activity, was not different between the theophylline and non-theophylline groups in both control and malnourished pups. Interestingly, both malnourished groups had a level of cellular activity significantly greater than the normally nourished groups. This has been observed in other models involving cellular stress (14).

Table 4. Brain DNA, RNA, protein content, and $\left.{ }^{\beta} H\right]$ thymidine incorporation into DNA ${ }^{\dagger}$

\begin{tabular}{|c|c|c|c|c|c|c|c|c|c|}
\hline \multirow[b]{2}{*}{ Maternal diet } & \multicolumn{2}{|c|}{ DNA } & \multicolumn{2}{|c|}{ RNA } & \multicolumn{2}{|c|}{ Protein } & \multirow[b]{2}{*}{ Protein/DNA } & \multirow[b]{2}{*}{ RNA/DNA } & \multirow{2}{*}{$\begin{array}{c}{\left[{ }^{3} \mathrm{H}\right] \text { Thymidine }} \\
\text { uptake } \\
(\mathrm{DPM} / \mu \mathrm{g})\end{array}$} \\
\hline & $\begin{array}{c}\text { Brain } \\
(\mu \mathrm{g} / \mathrm{mg})\end{array}$ & $\begin{array}{c}\text { Brain } \\
\text { (mg per) }\end{array}$ & $\begin{array}{c}\text { Brain } \\
(\mu \mathrm{g} / \mathrm{mg})\end{array}$ & $\begin{array}{c}\text { Brain } \\
\text { (mg per) }\end{array}$ & $\begin{array}{c}\text { Brain } \\
(\mu \mathrm{g} / \mathrm{mg})\end{array}$ & $\begin{array}{c}\text { Brain } \\
\text { (mg per) }\end{array}$ & & & \\
\hline $20 \%$ Protein $(n=18)$ & \pm 0.41 & \pm 0.54 & \pm 0.66 & \pm 0.88 & \pm 6.71 & \pm 8.99 & \pm 3.21 & \pm 0.21 & $\begin{array}{l} \pm 1.58 \\
n=6\end{array}$ \\
\hline \multirow{2}{*}{$\begin{array}{l}20 \% \text { Protein }+ \text { theophylline } \\
\quad(n=16)\end{array}$} & $1.99^{\prime *}$ & $2.67^{i *}$ & $2.76^{1 *}$ & 3.69 & 83.98 & 112.42 & $42.80^{t *}$ & 1.40 & 13.84 \\
\hline & \pm 0.33 & \pm 0.44 & \pm 0.63 & \pm 0.84 & \pm 7.38 & \pm 9.88 & \pm 6.09 & \pm 0.33 & $\begin{array}{c} \pm 3.48 \\
n=8\end{array}$ \\
\hline $6 \%$ Protein $(n=10)$ & \pm 0.56 & \pm 0.60 & \pm 0.51 & \pm 0.54 & \pm 8.97 & \pm 7.56 & \pm 14.51 & \pm 0.45 & \pm 2.77 \\
\hline \multirow{3}{*}{$\begin{array}{l}6 \% \text { Protein }+ \text { theophylline } \\
\quad(n=13)\end{array}$} & 2.21 & $2.26^{\mathrm{d} *}$ & $3.95^{\mathrm{d} *}$ & 4.04 & $96.01^{\mathrm{d} *}$ & $98.28^{i * d *}$ & $44.31^{t *}$ & $183^{\mathrm{d} *}$ & $\begin{array}{l}n=5 \\
1284\end{array}$ \\
\hline & \pm 0.37 & \pm 0.43 & \pm 0.66 & \pm 0.67 & \pm 11.60 & \pm 11.86 & \pm 5.40 & \pm 0.38 & \pm 2.42 \\
\hline & & & & & & & & & $n=8$ \\
\hline
\end{tabular}

\footnotetext{
${ }^{*} P<0.05 ;{ }^{* *} P<0.01 ; * * * P<0.001$
}

d, Significant difference due to dietary effect alone (i.e., $20 \%$ vs $6 \% ; 20 \%+$ theophylline vs $6 \%+$ theophylline).

$t$, Significant difference due to theophylline effect alone (i.e., $20 \%$ vs $20 \%+$ theophylline; $6 \%$ vs $6 \%+$ theophylline).

$\dagger$ Each value represents mean \pm SD. 
A dietary protein deficiency can affect the susceptibility to the toxicity of drugs or other agents such as pesticides and herbicides (2). At the present time, there are no such studies relative to theophylline, although the usage of theophylline is now quite common in the neonatal intensive care environment. Many infants therein who are now receiving theophylline therapeutically are being dosed on a body weight basis without consideration of the nutritional status. Our data suggest that, in the animal model, the administration of theophylline in the presence of a compromised nutritional status may have effects not now apparent. We add our concern to that expressed by others (16) that methylxanthine administration may have previously unsuspected effects on the developing brain.

\section{REFERENCES AND NOTES}

1. Berlin, C. M.: Excretion of the methylxanthines in human milk. Semin. Perinatol., 5: 389 (1981).

2. Boyd, E. M.: Diet and drug toxicity. Clin. Toxicol., 2: 423 (1969).

3. Enesco, M. and Leblond, C. P.: Increase in cell number as a factor in the growth of the young male rat. J. Embryol. Exp. Morphol., 10: 530 (1962).

4. Keenan, E. J., Klase, P. A., and Thomas, J. A.: Effects of prolactin on DNA synthesis and growth of the accessory sex organs in male mice. Endocrinology, 109: 170 (1981).

5. Kuzemko, J. A. and Paala, J.: Apneic attacks in the newborn treated with aminophylline. Arch. Dis. Child., 48: 404 (1973).

6. Lowry, O. H., Rosebrough, N. J., Farr, A. L., and Randall, R. J.: Protein measurement with folin phenol reagent. J. Biol. Chem., 193: 265 (1951).

7. Metha, S., Kalsi, H. K., Jajaraman, S., and Mathers, V. S.: Chloramphenicol metabolism in children with protein-calorie malnutrition. Am. J. Clin. Nutr., 28: 977 (1975).

8. Nakamoto, T. and Miller, S. A.: Effect of protein-energy malnutrition on the growth of mandible and long bone in newborn male and female rats. $J$. Nutr., 107: 983 (1977).

9. Nebron, R. M., Resnick, M. D., and Halstrum, W. J.: Developmental outcome of premature infants treated with theophylline. Dev. Pharmacol. Ther., 1: 274 (1980).

10. Newberne, P. M., Gross, R. L., and Roe, D. A.: Drug, toxin, nutrient interactions. World Rev. Nutr. Diet., 29: 130 (1978).

11. Pastorova, B., Sova, O., and Burda, J.: Incorporation of ${ }^{14} \mathrm{C}$-thymidine into liver and brain DNA of protein-deficient rats. Physiol. Bohemoslov., 27: 69 (1978).

12. Prasad, A. S., Dumouchell, E., Kovich, D., and Oberleas, D.: A simple fluorometric method for the determination of RNA and DNA in tissue. $J$ Lab. Clin. Med., 80: 598 (1972).

13. Varma, D. R.: Influence of dietary protein on the anti-inflammatory and ulcerogenic effects and on the pharmacokinetics of pheylbutazone in rats. $\mathbf{J}$ Pharmacol. Exp. Ther., 211: 338 (1979).

14. Winick, M. and Brasel, J.: Nutrition and Cell Growth. In R. S. Goodhart and M. E. Shills: Modern Nutrition in Health and Disease. p. 603 (Lea and Febiger, Philadelphia 1980).

15. Winick, M. and Noble, A.: Cellular response in rats during malnutrition at various ages. Dev. Biol., 12: 451 (1965).

16. Volpe, J. J.: Effects of methylxanthine on lipid synthesis in developing neural systems. Semin. Perinatol., 5: 395 (1981).

17. Based on the average body weight and the mean daily food intake in the dam fed each of the different diets during day 1 to 15 of postnatal period, the amount of theophylline was adjusted to $2 \mathrm{mg} / 100 \mathrm{~g}$ of body weight.

18. Requests for reprints should be addressed to: Dr. Griffith E. Quinby, Jr., Department of Pediatrics, Louisiana State University Medical Center, 1542 Tulane Avenue, New Orleans, Louisiana 70112.

19. Received for publication June 16, 1983.

20. Accepted for publication September 21, 1983.

\title{
Iron Deficiency in the Rat: Effects on Neutrophil Activation and Metabolism
}

\author{
BRUCE MACKLER, ${ }^{(20)}$ RICHARD PERSON, HANS OCHS, AND C. A. FINCH \\ Department of Pediatrics and Medicine, and the Center for Child Development and Mental Retardation, \\ University of Washington, Seattle, Washington, USA
}

\begin{abstract}
Summary
Studies were performed to determine the effects of iron deficiency in the rat on neutrophil activation and on levels of neutrophil myeloperoxidase and cytochrome $b$. The period of time required for neutrophil activation was not significantly affected by iron deficiency, but the maximum rates of respiration attained after activation were markedly lower $(60 \%$ decrease) in irondeficient neutrophils than in control cells. The myeloperoxidase activity of neutrophils from iron-deficient rats was also markedly decreased (approximately 75\%) compared with the activity of control cells; however, the concentration of cytochrome $b$ in the neutrophils was unaffected by iron deficiency.
\end{abstract}

\section{Abbreviations}

NBT, nitro blue tetrazolium

PMA, phorbol myristate acetate
A number of investigators have reported that iron deficiency in human subjects is associated with increased rates of infections, and that after treatment with iron supplements the high incidence of infections disappears [reviews by Chandra (4) and Strauss (18)]. Other investigators $(4,11)$ have shown that iron deficiency is associated with impaired immune functions, and that the abnormalities in immunocompetence appear to be reversible and to be related to the iron status as determined by transferrin saturation rather than hemoglobin concentration, suggesting that tissue deficiencies of iron-containing enzyme systems may be responsible. Chandra (3) demonstrated that neutrophils from iron-deficient children were defective in bactericidal activity and showed reduced NBT reduction after induction of phagocytosis. In addition, Higashi et al. (9) have reported studies which suggest that levels of myeloperoxidase may be lowered in the neutrophils of some patients with severe iron deficiency.

The present studies were undertaken to determine the iffects 